University of Nebraska - Lincoln

DigitalCommons@University of Nebraska - Lincoln

$12-2009$

\title{
Responses to "Comment on 'Response to Plevin: Implications for Life Cycle Emissions Regulations"' and "Assessing Corn Ethanol: Relevance and Responsibility"
}

\author{
Adam Liska \\ University of Nebraska - Lincoln, aliska2@unl.edu \\ Kenneth Cassman \\ Nebraska Center for Energy Sciences Research, UNL, kcassman1@unl.edu
}

Follow this and additional works at: https://digitalcommons.unl.edu/bseliska

Part of the Biological Engineering Commons

Liska, Adam and Cassman, Kenneth, "Responses to "Comment on 'Response to Plevin: Implications for Life Cycle Emissions Regulations"' and "Assessing Corn Ethanol: Relevance and Responsibility"' (2009). Adam Liska Papers. 8.

https://digitalcommons.unl.edu/bseliska/8

This Article is brought to you for free and open access by the Biological Systems Engineering at DigitalCommons@University of Nebraska - Lincoln. It has been accepted for inclusion in Adam Liska Papers by an authorized administrator of DigitalCommons@University of Nebraska - Lincoln. 
Published in Journal of Industrial Ecology 13:6 (December 2009), pages 994-995; DOI: 10.1111/j.1530-9290.2009.00187.x Copyright (C) 2009 by Yale University; published by Blackwell Publishing. Used by permission.

http://www.blackwellpublishing.com/jie

CORRESPONDENCE

\section{Letter to the Editor}

\section{Responses to "Comment on \\ 'Response to Plevin: Implications for Life Cycle Emissions Regulations"' and "Assessing Corn Ethanol: Relevance and Responsibility"}

This letter responds to two issues concerning the greenhouse gas (GHG) emissions intensity of corn-ethanol that were raised in discussions of our response (Liska and Cassman 2009) to Plevin's article (2009), which critiques our original research (Liska et al. 2009) published in the Journal of Industrial Ecology.

In our updated calculations, we found cornethanol to reduce GHG emissions by $47 \%$, on average, compared to gasoline (Liska and Cassman 2009). In Plevin's letter to the editor, he alters our modified result to arrive at $35 \%$ reduction. This alteration is due to a change in one variable, namely, the GHG emissions intensity of gasoline. Due to increases in the tar sands fraction in USA gasoline, we recently estimated that the current GHG emissions intensity of US average gasoline is $97.7 \mathrm{gCO}_{2} \mathrm{e} \mathrm{MJ}$ (Liska and Perrin 2009). Plevin asserts that we miscalculated this result. Our difference lies in the baseline GHG emissions intensity of pure gasoline: Plevin uses the older value of 92.0 $\mathrm{gCO}_{2} \mathrm{e} \mathrm{MJ}{ }^{-1}$, while we used $96.9 \mathrm{gCO}_{2} \mathrm{e} \mathrm{MJ}$ which reflects current California reformulated blendstock without the addition of ethanol (California Air Resources Board 2009). We have previously argued that the GHG intensity of pure ethanol should be compared with pure petroleum-based gasoline, which provides an "apples to apples" comparison (Liska and Cassman 2009). Assuming $96.9 \mathrm{gCO}_{2} \mathrm{e} \mathrm{MJ}^{-1}$ as the baseline for pure petroleum-based gasoline and
$7 \%$ of U.S. gasoline is derived from tar sands, we used the updated value for the GHG intensity of tar sands derived gasoline (Charpentier et al. 2009) to arrive at our result of $97.7 \mathrm{gCO}_{2} \mathrm{e}$ $\mathrm{MJ}^{-1}(0.07$ * $108.1+0.93$ * 96.9) (Liska and Perrin 2009). Thus, we argue that Plevin's recalculation of the GHG baseline of U.S. gasoline underestimates the GHG intensity of this fuel, and the best available evidence still supports our conclusion that corn-ethanol reduces GHG emissions compared to contemporary gasoline by $47 \%$ (Liska and Cassman 2009).

Furthermore, Anex and Lifset (2009) suggest that the use of IPCC emission factors in the BESS model underestimates corn-ethanol's life cycle emissions, which are assumed to be more closely estimated using GREET upstream emission factors. While some emissions factors are likely underestimated using IPCC values instead of GREET values, our calculations have previously shown that the choice between these two sets of emission factors has negligible impact on the GHG intensity as calculated using the BESS and GBAMM models. In our previous response to Plevin (2009), we showed that using GBAMM, which has all of GREET's emissions factors, and including a modified co-product credit from BESS, we arrive at $51.5 \mathrm{gCO}_{2} \mathrm{e}$ $\mathrm{MJ}^{-1}$ for the GHG intensity of corn-ethanol (Liska and Cassman 2009). Likewise, the modified GHG emissions intensity calculated with the BESS model results in a life cycle intensity of $51.8 \mathrm{gCO}_{2} \mathrm{e} \mathrm{MJ}{ }^{-1}$ (corresponding to the $47 \%$ reduction). Thus, estimated corn-ethanol emissions are within $1 \%$ of each other when using the combination of GBAMM and GREET values or BESS and IPCC values. In large part this results from the fact that as emission factors increase in intensity (e.g. in GREET vs. IPCC), the 
co-product credit in the corn-ethanol life cycle also increases, which partially offsets the positive emissions. Thus, the suggestion by Anex and Lifset (2009) that corn-ethanol does not reduce GHG emissions by $47 \%$ compared to gasoline, but instead by "somewhere between" 35 to $40 \%$, is unsubstantiated.

Adam J. Liska and Kenneth G. Cassman University of Nebraska-Lincoln

Lincoln, NE 68583-0726

\section{References}

Anex, R. and R. Lifset. 2009. Assessing corn ethanol: Relevance and responsibility. Journal of Industrial Ecology 13(4): 479-482.

California Air Resources Board. 2009. Detailed CAGREET Pathway for California ReformulatedGasoline Blendstock for Oxygenate Blending (CARBOB) from Average Crude Refined in California. Sacra- mento, CA, USA: Stationary Source Division, California Air Resources Board. Version: 2.0, Release Date: January 12. http://www.arb.ca.gov/fuels/ lcfs/011209lcfs_carbob.pdf [February 2009].

Charpentier, A. D., J. A. Bergerson, and H. L. MacLean. 2009. Understanding the Canadian oil sands industry's greenhouse gas emissions. Environmental Research Letters 4(1): 014005.

Liska, A. J. and K. G. Cassman. 2009. Response to Plevin: Implications for life cycle emissions regulations. Journal of Industrial Ecology 13(4): 508- 513.

Liska, A. J. and R. K. Perrin. 2009. Indirect land use emissions in the life cycle of biofuels: Regulations vs. science. Biofuels, Bioproducts, and Biorefining 3(3): 318-328.

Liska, A. J., H. S. Yang, V. R. Bremer, T. J. Klopfenstein, D. T. Walters, G. E. Erickson, and K. G. Cassman. 2009. Improvements in life cycle energy efficiency and greenhouse gas emissions of cornethanol. Journal of Industrial Ecology 13(1): 58-74.

Plevin, R. J. 2009. Modeling corn ethanol and climate: A critical review of the BESS and GREET models. Journal of Industrial Ecology 13(4): 495-507. 